\title{
Improved Synthesis of No-Carrier-Added [*I]MIBG and Its Precursor
}

\author{
Friedrich Hammerschmidt, ${ }^{* a}$ Herbert Kvaternik, ${ }^{* b, c}$ Anna Schweifer, ${ }^{\dagger a}$ Kurt Mereiter, ${ }^{\text {d Reingard M. Aigner }}{ }^{b}$ \\ a Institute of Organic Chemistry, University of Vienna, Währingerstraße 38, 1090 Vienna, Austria \\ Fax+43(1)42779521; E-mail: friedrich.hammerschmidt@univie.ac.at \\ b Department of Nuclear Medicine, Medical University of Graz, Auenbruggerplatz 9, 8036 Graz, Austria \\ Fax+43(316)38512151; E-mail: herbert.kvaternik@medunigraz.at \\ c Radiopharmaceuticals, Seibersdorf Labor GmbH, 2444 Seibersdorf, Austria \\ d Institute of Chemical Technologies and Analytics, Vienna University of Technology, Getreidemarkt 9/164SC, 1060 Vienna, Austria \\ Received: 09.07.2012; Accepted after revision: 10.09.2012 \\ $\dagger$ Deceased December 29, 2010
}

\begin{abstract}
Trimethylstannyl)benzyl alcohol was coupled in a Mitsunobu reaction with bis(Boc)-guanidine to give bis(Boc)-protected 3-(trimethylstannyl)benzylguanidine used as precursor for [*I]MIBG. Radioiodination with $\left[{ }^{131} \mathrm{I}\right]$ iodine generated from $\left.{ }^{[131} \mathrm{I}\right] \mathrm{NaI}$ and chloramine-T, removal of Boc groups, and purification by HPLC gave no-carrier-added tracer [ ${ }^{*}$ ] MIBG $(81 \%$ radiochemical yield, $99 \%$ chemical purity) used for imaging tumors of neuroendocrine origin. The structures of bis(Boc)-guanidine and bis(Boc)-protected 3-(trimethylstannyl)benzylguanidine were secured by single crystal X-ray structure analyses.
\end{abstract}

Key words: Mitsunobu reaction, electrophilic aromatic substitution, medicinal chemistry, $\left[{ }^{131} \mathrm{I}\right]$ iodine, halogenation

$m$-Iodobenzylguanidine (MIBG) labeled with radioiodine ${ }^{131} \mathrm{I}$ or ${ }^{123} \mathrm{I}$ is an analogue of the andrenergic neuron-blocking agent guanethidine and of norepinephrine being mainly biosynthesized in the adrenal medulla. ${ }^{1}$ Since 1980 $\left[{ }^{*}\right]$ MIBG is well-established in diagnostic scintigraphy and widely applied in imaging tumors of neuroendocrine origin, particularly neuroblastoma and pheochromocytoma. ${ }^{2-4}\left[{ }^{*} \mathrm{I}\right] \mathrm{MIBG}$ as a norepinephrine analogue is concentrated in the myocardium and has been used for severity assessment of cardiac diseases. ${ }^{5}$ Labeled $\left.{ }^{[31} \mathrm{I}\right] \mathrm{MIBG}$ is also effective in the therapeutic treatment of pediatric neuroblastoma. ${ }^{6}$ Currently, $\left.{ }^{*} \mathrm{I}\right] \mathrm{MIBG}$, routinely applied in clinical diagnostic imaging and therapy, is prepared by nucleophilic isotope exchange reaction. This kind of radiopharmaceutical preparation may contain a pharmaceutically significant amount of cold MIBG $(1-5 \mathrm{mg}) .^{7}$ The first published labeling method was based on a solidphase radioiodine exchange reaction assisted by ammonium sulfate. ${ }^{8}$ Later several modifications of this method have been reported. The isotope exchange was also catalyzed by $\mathrm{Cu}(\mathrm{I})$ in the presence of a reducing agent such as $\mathrm{Sn}(\mathrm{II})$, ascorbic acid, 2,5-dihydroxybenzoic acid, or sodium metabisulfite. ${ }^{9-11}$ Instead of a solid-phase reaction, the labeling of MIBG can be performed in refluxing glacial acetic acid. ${ }^{10,12}$

SYNTHESIS 2012, 44, 3387-3391

Advanced online publication: 28.09 .2012

DOI: 10.1055/s-0032-1316789; Art ID: SS-2012-T0576-OP

(C) Georg Thieme Verlag Stuttgart · New York
However, the synthesis of [*I]MIBG via isotope exchange reaction has some distinct disadvantages. Firstly, byproducts such as radiolabeled iodobenzylamine may be formed as impurities during the radioiodination. ${ }^{11}$ Secondly, due to the method of preparation the formulation contains a considerable amount of unlabeled cold MIBG, which may influence the pharmacokinetics of the radiolabeled form. ${ }^{2}$ Therefore, it would be advantageous to prepare $\left[{ }^{*}\right.$ I]MIBG containing virtually no cold MIBG. The first reported approaches to synthesize no-carrier-added [*I]MIBG relied on a tributylstannyl- or silyl-substituted precursor. ${ }^{13}$ In the latter case, radiochemical yields varied from $85-90 \%$ in addition to the formation of benzyl-, 3chloro-, and 3-fluorobenzylguanidine as by-products. Recently, $N, N^{\prime}$-bis(tert-butoxycarbonyl)- $N$-(3-trimethylstannylbenzyl)guanidine prepared from the corresponding iodo derivative by Pd-catalyzed stannylation as (impure) oils in $43 \%$ and $57 \%$ yield, respectively, was used as precursor for iododestannylation. ${ }^{14,15}$

Our synthesis of [*I]MIBG is also based on iododestannylation of 3-(trimethylstannyl)benzylguanidine. ${ }^{14,15}$ Initially, the preparation of this precursor was tried in two steps by a literature procedure. ${ }^{16}$ First, 3-iodobenzylamine was treated with hexamethylditin and tetrakis(triphenylphosphine)palladium $(0)$ to obtain the corresponding 3-(trimethylstannyl)benzylamine, which was described as a crystalline solid $\left(\mathrm{mp} 78^{\circ} \mathrm{C}\right) .{ }^{16}$ However, it was found to be an oil (bp $98^{\circ} \mathrm{C} / 1 \mathrm{mmHg}$ ), which was also supported by literature. ${ }^{17}$ Furthermore, the yield of stannylation was unsatisfactorily low (25\%). The second step was the conversion of the amine with cyanamide in the presence of a catalytic amount of $\mathrm{HCl}$ to the guanidine, which was claimed to be an oil. We repeated this transformation, but the result was inconclusive.

Therefore, it was decided to prepare the amine and the guanidine by a different approach (Scheme 1). Halogenmetal exchange in 3-iodobenzyl alcohol (1a) with $t$-BuLi (3.2 equiv) at $-78{ }^{\circ} \mathrm{C}$ in anhydrous THF followed by 1.5 equivalents of $\mathrm{Me}_{3} \mathrm{SnCl}$ gave at best $23 \%$ of 3-(trimethylstannyl)benzyl alcohol (2). The yield could be increased to $69 \%$, when $t$-BuLi was replaced by $n$-BuLi (3.2 equiv, $90 \mathrm{~min},-78^{\circ} \mathrm{C}, 1.5$ equiv of $\mathrm{Me}_{3} \mathrm{SnCl}$, THF). The yield was even better (93\%), when 3-bromobenzyl alcohol (1b) 
was used as the substrate $(2.3$ equiv of $n$-BuLi for halogen-lithium exchange at $-78^{\circ} \mathrm{C}$ in THF for $90 \mathrm{~min}, 2.1$ equiv of $\mathrm{Me}_{3} \mathrm{SnCl}$ ). This method was used previously for the preparation of 3-(tributylstannyl)benzyl alcohol. ${ }^{18}$

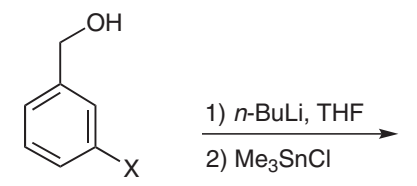

$$
\text { 1a } X=1
$$$$
\text { 1b } X=B r
$$$$
\begin{aligned}
& 69 \% \\
& 93 \%
\end{aligned}
$$

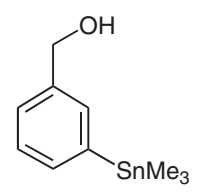

2

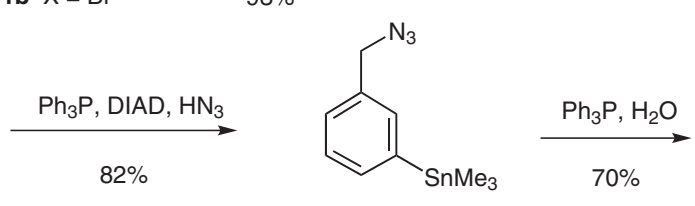

3

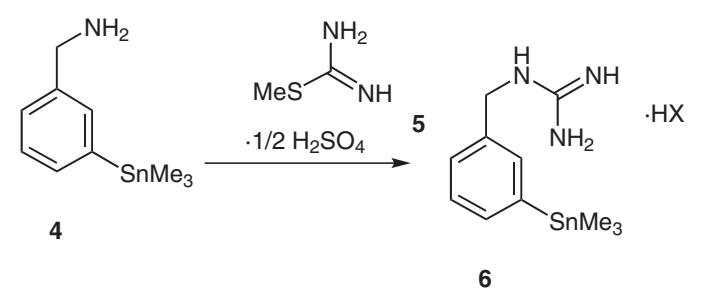

Scheme 1 Synthesis of precursor 6

The 3-(trimethylstannyl)benzyl alcohol (2) was converted into the azide $^{17} 3$ by the Mitsunobu reaction ${ }^{19}$ in $82 \%$ yield and then reduced ${ }^{17}$ to the oily benzylamine 4 in $70 \%$ yield. The amine had been prepared earlier from (3-bromobenzyl)dimethylamine by Koldobsky et al. in three steps. ${ }^{17}$ The guanidinylation of $\mathbf{4}$ could have been effected, for example, by reaction with cyanamide, ${ }^{16}$ Mukaiyama's reagent, and thioureas, ${ }^{20}$ or $N, N^{\prime}$-bis(tert-butoxycarbonyl)$N^{\prime \prime}$-triflylguanidine. ${ }^{21}$ None of this method was tried, as it had been found ${ }^{22}$ in the meantime that the Mitsunobu reaction of alcohol 2 with $N, N^{\prime}$-bis(tert-butoxycarbonyl)guanidine could give a protected precursor in high yield, which could be purified by flash column chromatography. Alternatively, the benzyl alcohol could be transformed into the bromide, which is then reacted with the sodium salt of $N, N^{\prime}$-bis(tert-butoxycarbonyl)guanidine. ${ }^{23}$ As the Mitsunobu reaction was our first choice, the protected guanidine was prepared first and the literature procedures were optimized (Scheme 2). Commercially available $S$-mehylisothiourea hemisulfate was Bocprotected $^{24}$ in $91 \%$ yield in the biphasic system $\mathrm{NaHCO}_{3} / \mathrm{H}_{2} \mathrm{O} / \mathrm{Boc}_{2} \mathrm{O} / \mathrm{CH}_{2} \mathrm{Cl}_{2}$. N-tert-Butoxycarbonylmethylisothiourea $(8)$, formed as a side product $(8 \%)$, could be removed easily by flash chromatography. Exchange of the methylthio group for amine with ammonia in methanol furnished the bis(Boc)-protected guanidine 9a in 95\% yield. ${ }^{22}$ Interestingly, Feichtinger et al. reported that $9 \mathbf{b}$ was formed from guanidine and $\mathrm{Boc}_{2} \mathrm{O}$ under strong alkaline conditions in $59 \%$ yield. ${ }^{21}$ In the literature, structures $^{19,22} \mathbf{9 a}$ and in one case ${ }^{21} \mathbf{9 b}$ are given for bis(Boc)-guanidine without providing evidence. To solve this ambiguity, a single crystal X-ray analysis was per- formed proving structure 9a for the solid state (Figure 1). We assume that this is also the structure of bis(Boc)guanidine in solution.
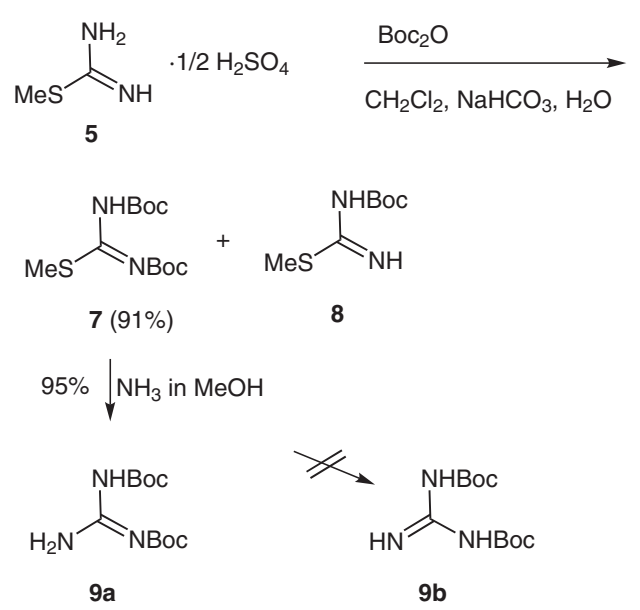

Scheme 2 Improved synthesis of bis(Boc)-guanidine 9a

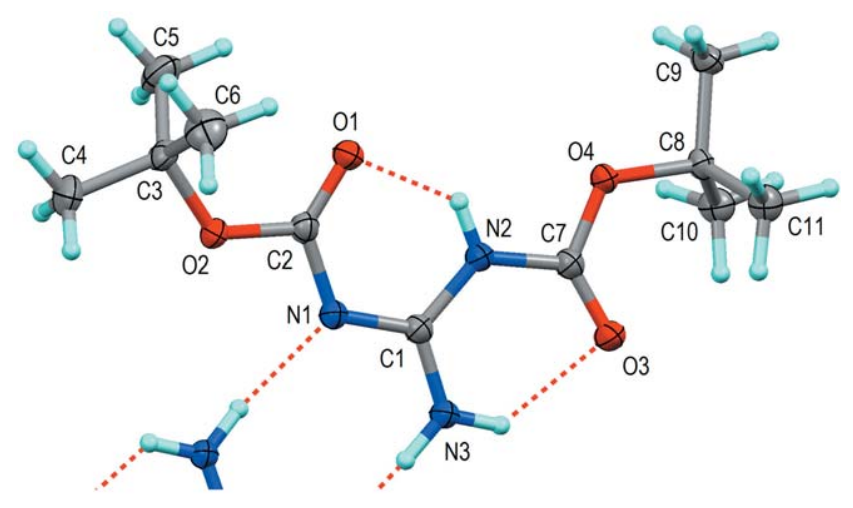

Figure 1 Molecular structure of 9a with hydrogen bonds as dashed lines

Finally, 9a and 3-(trimethylstannyl)benzyl alcohol (2) were reacted in a Mitsunobu reaction with $\mathrm{Ph}_{3} \mathrm{P} / \mathrm{DIAD}$ (diisopropyl azodicarboxylate) in anhydrous toluene to give the desired precursor 10, which was isolated by flash chromatography (87\%) (Scheme 3). ${ }^{22}$ Satisfyingly, precursor 10 crystallized (from hexanes) to give colorless crystals. The same precursor had been prepared earlier as an oil by the reaction of 3-iodobenzyl bromide with the sodium salt of bis(Boc)-guanidine, followed by exchange of the iodine for trimethyltin using $\mathrm{Pd}\left(\mathrm{Ph}_{3} \mathrm{P}\right)_{4} / \mathrm{Me}_{6} \mathrm{Sn}_{2}$ $(57 \%) .{ }^{15}$ Iododestannylation and removal of protecting groups furnished the tracer.

When this work was finished, we found that the bis(Boc)protected guanidine is commercially available. Thus, our synthesis comprises just two steps starting from 3-bromobenzyl alcohol, which is also commercially available.

As the precursor was described as an oil ${ }^{14,15}$ (chemical purity 94\%) in the literature and ours was crystalline, and although the ${ }^{1} \mathrm{H}$ NMR spectra were virtually identical, we decided to perform a single crystal X-ray structure analysis (Figure 2). Satisfyingly, it proved the structure of com- 


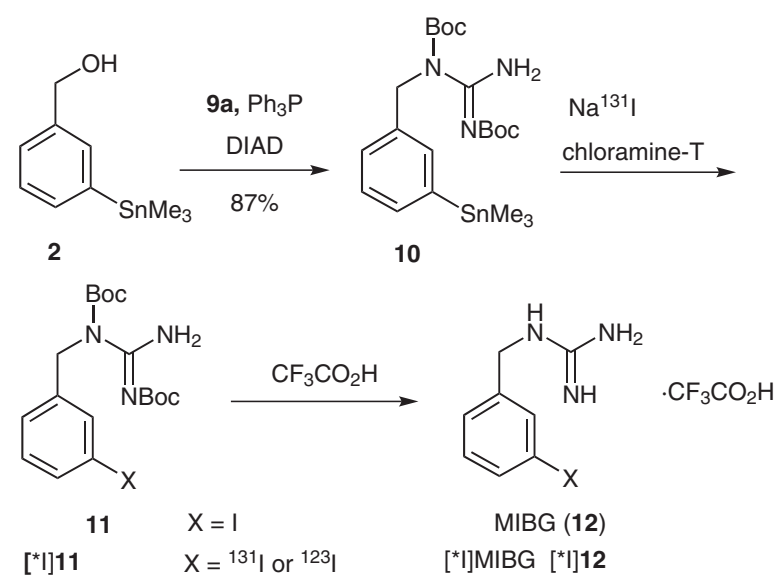

Scheme 3 Improved synthesis of precursor 10 and [*I]MIBG

pound $\mathbf{1 0}$ as given in Scheme 3, which is also in line with 9a. The molecular structure is stabilized by two short internal hydrogen bonds $(\mathrm{N} \cdots \mathrm{O}=2.57$ and $2.61 \AA$; Figure 2), which control its conformation.

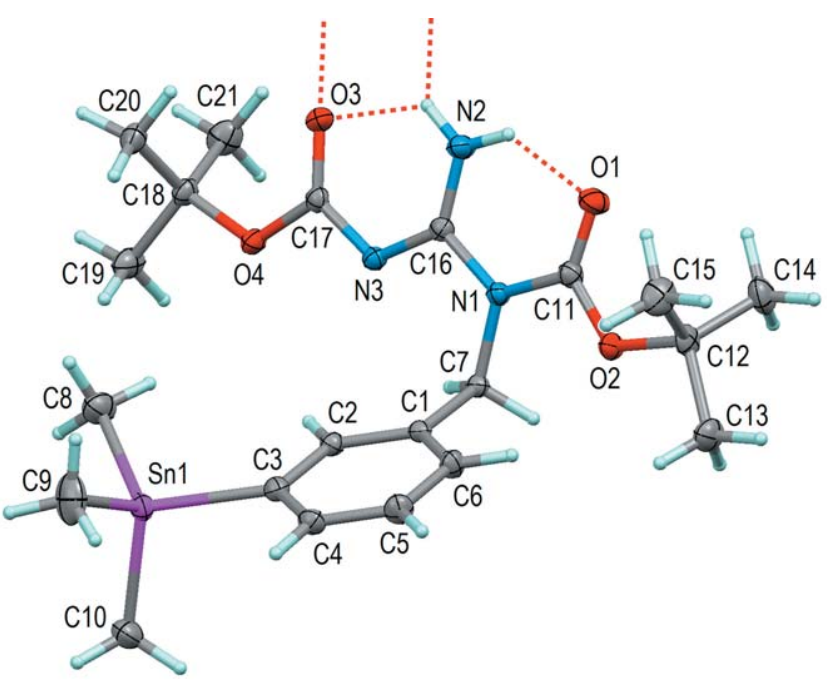

Figure 2 Molecular structure of precursor 10 with hydrogen bonds as dashed lines

This result shows that compound $\mathbf{1 3}$, an isomer of $\mathbf{1 0}$, is not formed (Figure 3). The nucleophile derived from 9 in the Mitsunobu reaction is the one obtained by deprotonation at the nitrogen atom attached to a Boc group.<smiles>COC(=O)c1cccc(CN(C(=O)OCc2ccccc2)C(N)=NC(=O)OCc2ccccc2)c1</smiles>

10

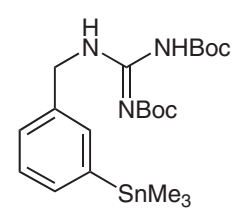

13
Radioiodination of the precursor $N, N^{\prime}$-bis(Boc)- $N$-(3-trimethylstannylbenzyl)guanidine (10) with no-carrieradded $\left[{ }^{123} \mathrm{I}\right] \mathrm{NaI}$ and $\mathrm{N}$-chlorosuccinimide (NCS) as an in situ oxidizing agent has been recently reported. Rossouw et al. described the use of $2000 \mu \mathrm{g}$ of NCS as an oxidant a 10-fold mass excess relative to precursor 10 - which appeared to us as nonoptimal. We argued that the large excess of NCS could interfere with the final purification of the tracer by HPLC or by using a solid phase cartridge. Therefore, it was decided to replace NCS with chloramine-T, also a well known oxidizing agent. ${ }^{25,26}$ The reaction of $200 \mu \mathrm{g}$ of $\mathbf{1 0}$ dissolved in $\mathrm{MeOH}-\mathrm{AcOH}$ with nocarrier-added $\left[{ }^{131} \mathrm{I}\right] \mathrm{NaI}$ and only $60 \mu \mathrm{g}$ of chloramine-T at room temperature resulted in the almost quantitative formation of the bis(Boc)-protected 3-[ $\left.{ }^{131} \mathrm{I}\right]$ iodobenzylguanidine intermediate $\left[{ }^{131} \mathrm{I}\right] 11$. Here, the labeling reaction was monitored by radio TLC. Since the reaction mixture contained acetic acid, a slight removal of the Boc groups from $\left[{ }^{131} \mathrm{I}\right] 11$ was observed already during labeling. After deactivation of the oxidant with sodium metabisulfite, the complete removal of the protecting groups was performed with $\mathrm{CF}_{3} \mathrm{CO}_{2} \mathrm{H}$ at $110^{\circ} \mathrm{C}$ for 10 minutes to give the crude $\left[{ }^{131} \mathrm{I}\right] \mathrm{MIBG}\left(\left[{ }^{131} \mathrm{I}\right] \mathrm{12}\right)$. After neutralization with $\mathrm{NaOH}$, the labeled $\left[{ }^{131} \mathrm{I}\right] \mathrm{MIBG}$ was purified by semi-preparative HPLC. Up to $98 \%$ of the starting radioactivity could be isolated as $\left[{ }^{131} \mathrm{I}\right] \mathrm{MIBG}$. A small amount of unreacted $\left[{ }^{131} \mathrm{I}\right] \mathrm{NaI}$ was detected in the reaction mixture, but no significant quantities of by-products were found. The solvent was gently removed at $35^{\circ} \mathrm{C}$ under reduced pressure from the pooled fractions containing $\left[{ }^{131} \mathrm{I}\right] \mathrm{MIBG}$. The dry residue was redissolved in phosphate-buffered saline-5\% EtOH. To prevent decomposition by radiolysis 2,5-dihydroxybenzoic acid and benzyl alcohol were added as preservatives. ${ }^{27,28}\left[{ }^{131} \mathrm{I}\right] \mathrm{MIBG}$ was isolated with an overall radiochemical yield of $81 \pm 3 \%(n=4)$.

The purity of $\left[{ }^{131} \mathrm{I}\right] \mathrm{MIBG}$ was assessed with radio TLC and radio HPLC by comparison with an authentic nonradioactive reference sample. The amount of cold MIBG (2 $\mu \mathrm{g})$ in a batch of $\left[{ }^{131} \mathrm{I}\right] \mathrm{MIBG}$, was determined by HPLC, resulting in a specific activity of $>11 \mathrm{GBq} / \mu \mathrm{mol}$. The radiochemical purity of the isolated $\left[{ }^{131} \mathrm{I}\right] \mathrm{MIBG}$ was $>99 \%$ and the final formulations remained stable for more than 20 hours.

In conclusion, we have developed a concise synthesis of a trimethylstannylated precursor, which allows a no-carrier-added labeling with radioiodine to form [*I]MIBG. As a novel approach, the radiolabeling reaction was carried out successfully using chloramine-T as oxidant. It was shown that the $\left[{ }^{*} \mathrm{I}\right] \mathrm{MIBG}$ could be obtained in high yield and purity under mild reaction conditions. The labeling process appears to be amenable for automation, which is applicable to all radioiodine isotopes and allows large scale routine production of [*I]MIBG for radiopharmaceutical use.

\footnotetext{
Figure 3 Isomeric compounds $\mathbf{1 0}$ and $\mathbf{1 3}$

Figure 3 Isomeric compounds 10 and 13
} 
${ }^{1} \mathrm{H}$ and ${ }^{13} \mathrm{C}$ NMR spectra ( $J$ modulated) were measured in $\mathrm{CDCl}_{3}$ at $300 \mathrm{~K}$ on a Bruker Avance DRX 400 spectrometer at $400.13 \mathrm{MHz}$ and $100.63 \mathrm{MHz}$, respectively. Chemical shifts were referenced to residual $\mathrm{CHCl}_{3}\left(\delta_{\mathrm{H}}=7.24\right)$ and $\mathrm{CDCl}_{3}\left(\delta_{\mathrm{C}}=77.00\right)$. IR spectra were run on a PerkinElmer 1600 FT-IR spectrometer; liquid samples were measured as films on a silicon disc. ${ }^{29}$ Crystal structures were analyzed using a Bruker AXS APEX CCD diffractometer. TLC was carried out on $0.25 \mathrm{~mm}$ thick Merck plates, silica gel $60 \mathrm{~F}_{254}$. Flash (column) chromatography was performed with Macherey-Nagel silica gel 60M (230-400 mesh). Spots were visualized by UV and/or dipping the plate into a solution of $\left(\mathrm{NH}_{4}\right)_{6} \mathrm{Mo}_{7} \mathrm{O}_{24} \cdot 4 \mathrm{H}_{2} \mathrm{O}$ $(23.0 \mathrm{~g})$ and of $\mathrm{Ce}\left(\mathrm{SO}_{4}\right)_{2} \cdot 4 \mathrm{H}_{2} \mathrm{O}(1.0 \mathrm{~g})$ in $10 \% \mathrm{aq} \mathrm{H}_{2} \mathrm{SO}_{4}(500 \mathrm{~mL})$, followed by heating with a heat gun. $S$-Methylisothiuronium hemisulfate was obtained from Aldrich. Melting points were determined on a Reichert Thermovar instrument and are uncorrected.

\section{Radiosynthesis}

No-carrier-added $\left[{ }^{131} \mathrm{I}\right] \mathrm{NaI}$ in $0.1 \mathrm{M} \mathrm{NaOH}$ was obtained from PerkinElmer (Boston, MA, USA). The radioactivity was measured in a Capintec CRC-15 dose calibrator (Ramsey, NJ, USA). Analytical high-performance liquid chromatography (HPLC) analyses were performed on an Agilent 1200 system (Böblingen, Germany) equipped with a quaternary pump, autosampler, and a variable wavelength spectrophotometer, which was connected in series with a Raytest radioactivity detector (Straubenhardt, Germany). Data were collected by Raytest radio chromatography software. RadioTLCs were evaluated using an electronic autoradiograph (CanberraPackard, Watford, UK).

\section{3-(Trimethylstannyl)benzyl Alcohol (2)}

$n$-BuLi (5.75 mL, 9.2 mmol, 2.3 equiv, 1.6 M solution in hexanes) was added dropwise to a stirred solution of 3-bromobenzyl alcohol (1b; $0.748 \mathrm{~g}, 0.48 \mathrm{~mL}, 4.0 \mathrm{mmol})$ in anhyd THF $(18 \mathrm{~mL})$ at $-78{ }^{\circ} \mathrm{C}$ under argon. After stirring for $90 \mathrm{~min}$ at $-78{ }^{\circ} \mathrm{C}, \mathrm{Me}_{3} \mathrm{SnCl}(1.674 \mathrm{~g}$, $8.4 \mathrm{mmol}, 2.1$ equiv) dissolved in anhyd THF $(7.5 \mathrm{~mL})$ was added, and the reaction mixture was stirred for $18 \mathrm{~h}$ at r.t. (TLC: hexanesEtOAc, 5:1). The reaction was quenched with aq $5 \% \mathrm{NH}_{4} \mathrm{Cl}(20$ $\mathrm{mL}$ ). The organic phase was separated and the aqueous layer was extracted with $\mathrm{CH}_{2} \mathrm{Cl}_{2}(3 \times 20 \mathrm{~mL})$. The combined organic layers were dried $\left(\mathrm{Na}_{2} \mathrm{SO}_{4}\right)$ and concentrated under reduced pressure. The crude product was purified by flash chromatography (hexanesEtOAc, 5:1, $\left.R_{f}=0.29\right)$ to give stannyl alcohol $2(1.013 \mathrm{~g}, 93 \%)$ as a colorless oil.

IR (Si, film): 3332, 2980, 2914, 1411, $1203 \mathrm{~cm}^{-1}$.

${ }^{1} \mathrm{H} \mathrm{NMR}\left(\mathrm{CDCl}_{3}\right): \delta=7.54-7.28(\mathrm{~m}, 4 \mathrm{H}), 4.67$ (s, $\left.2 \mathrm{H}\right), 1.76$ (br s, $1 \mathrm{H}, \mathrm{OH}), 0.29\left[\mathrm{~s}, J\left({ }^{117 / 119} \mathrm{Sn}, \mathrm{C}\right)=55.3,52.8 \mathrm{~Hz}, 9 \mathrm{H}\right]$.

${ }^{13} \mathrm{C}$ NMR $\left(\mathrm{CDCl}_{3}\right): \delta=142.7,140.2,135.2\left[J\left({ }^{117 / 119} \mathrm{Sn}, \mathrm{C}\right)=36.0\right.$ $\mathrm{Hz}], 134.4\left[J\left({ }^{117 / 119} \mathrm{Sn}, \mathrm{C}\right)=35.9 \mathrm{~Hz}\right], 128.2\left[J\left({ }^{117 / 119} \mathrm{Sn}, \mathrm{C}=45.9\right.\right.$ $\mathrm{Hz}], \quad 127.0 \quad\left[J\left({ }^{117 / 119} \mathrm{Sn}, \mathrm{C}\right)=10.7 \mathrm{~Hz}\right], 65.6, \quad-9.6 \quad[3 \mathrm{C}$, $\left.J\left({ }^{117 / 119} \mathrm{Sn}, \mathrm{C}\right)=351.1,335.8 \mathrm{~Hz}\right]$.

Anal. Calcd for $\mathrm{C}_{10} \mathrm{H}_{16} \mathrm{OSn}$ : C, 44.33; H, 5.95. Found: C, 44.75; $\mathrm{H}$, 5.86 .

\section{3-(Trimethylstannyl)benzyl Azide (3)}

Diisopropyl azodicarboxylate $(0.281 \mathrm{~g}, 1.16 \mathrm{mmol}, 0.27 \mathrm{~mL}, 1.2$ equiv) and $\mathrm{HN}_{3}(0.98 \mathrm{~mL}, 1.41 \mathrm{M}$ in toluene, $1.39 \mathrm{mmol}, 1.2$ equiv) were added dropwise to a solution of 3-(trimethylstannyl)benzyl alcohol $(2 ; 0.313 \mathrm{~g}, 1.16 \mathrm{mmol})$ and $\mathrm{Ph}_{3} \mathrm{P}(0.359 \mathrm{~g}, 1.39 \mathrm{mmol}, 1.2$ equiv) in anhyd toluene $(6.9 \mathrm{~mL})$ at $0{ }^{\circ} \mathrm{C}$ under argon. After stirring for $18 \mathrm{~h}$ at r.t., no alcohol could be detected by TLC (hexanesEtOAc, 5:1). The solvent was removed under reduced pressure and the residue was flash chromatographed (hexanes, $R_{f}=0.25$ ) to yield azide $3(0.283 \mathrm{~g}, 82 \%)$ as a colorless oil. The ${ }^{1} \mathrm{H}$ NMR spectrum was identical to that reported in the literature. ${ }^{17}$

\section{$N, N^{\prime}$-Bis(tert-butoxycarbonyl)- $S$-methylisothiourea (7)}

A mixture of $S$-methylisothiuronium hemisulfate $(\mathbf{5} ; 1.392 \mathrm{~g}, 10.0$ $\mathrm{mmol})$, di(tert-butyl) dicarbonate $(4.36 \mathrm{~g}, 20 \mathrm{mmol}, 2$ equiv), $\mathrm{CH}_{2} \mathrm{Cl}_{2}(25 \mathrm{~mL})$, and sat. aq $\mathrm{NaHCO}_{3}(25 \mathrm{~mL})$ was vigorously stirred for 3 days at r.t. The layers were separated, and the aqueous phase was extracted with $\mathrm{CH}_{2} \mathrm{Cl}_{2}(3 \times 20 \mathrm{~mL})$. The combined organic layers were dried $\left(\mathrm{Na}_{2} \mathrm{SO}_{4}\right)$ and concentrated under reduced pressure. The crude product was a mixture of $N$-(tert-butoxycarbonyl)-S-methylisothiourea $(8)\left(R_{f}=0.06\right.$, hexanes- $\left.\mathrm{CHCl}_{3}, 1: 6\right)$ and 7 $\left(R_{f}=0.31\right.$, hexanes- $\left.\mathrm{CHCl}_{3}, 1: 6\right)$. Flash chromatography (hexanesEtOAc, 7:1; TLC: hexanes-EtOAc, 5:1, $\left.R_{f}=0.81\right)$ yielded 7 (2.643 $\mathrm{g}, 91 \%$ ) as colorless needles; mp $120-121^{\circ} \mathrm{C}$ (hexanes) (Lit. ${ }^{24} \mathrm{mp}$ $\left.122-123{ }^{\circ} \mathrm{C}\right)$.

IR (Si, film): 2982, 1741, 1645, 1575, 1363, 1285, $1139 \mathrm{~cm}^{-1}$.

${ }^{1} \mathrm{H} \mathrm{NMR}\left(\mathrm{CDCl}_{3}\right): \delta=11.57$ (s, $\left.1 \mathrm{H}\right), 2.37$ (s, $\left.3 \mathrm{H}\right), 1.49$ (s, $\left.18 \mathrm{H}\right)$.

${ }^{13} \mathrm{C} \mathrm{NMR}\left(\mathrm{CDCl}_{3}\right): \delta=171.40$ (2 C), 28.00 (6 C), 14.79 .

The ${ }^{1} \mathrm{H}$ NMR spectrum was identical to the one reported in the literature $;{ }^{24}$ no ${ }^{13} \mathrm{C}$ NMR spectrum was given.

\section{$N, N^{\prime}$-Bis(tert-butoxycarbonyl)guanidine (9a)}

A solution of $\mathrm{NH}_{3}$ in $\mathrm{MeOH}\left(18 \mathrm{~mL}, 11.7 \mathrm{~g} \mathrm{NH}_{3}\right.$ in $70 \mathrm{~mL}$ of anhyd $\mathrm{MeOH})$ was added to $N, N^{\prime}$-bis(tert-butoxycarbonyl)- $S$-methylisothiourea $(7 ; 0.935 \mathrm{~g}, 3.22 \mathrm{mmol})$. The mixture was stirred for $18 \mathrm{~h}$ at r.t. The solvent was evaporated under reduced pressure and the residue was purified by flash chromatography (hexanes-EtOAc, $2: 1 ; R_{f}=0.27$, hexanes-EtOAc, $\left.5: 1\right)$ to give guanidine 9a $(0.793 \mathrm{~g}$, $95 \%$ ) as colorless crystals; $\mathrm{mp} 143-144{ }^{\circ} \mathrm{C}$ (hexanes) (Lit. ${ }^{22} \mathrm{mp}$ $144{ }^{\circ} \mathrm{C}$; Lit. ${ }^{21} \mathrm{mp} 144-145^{\circ} \mathrm{C}$ ).

IR (Si, film): 3411, 2980, 1732, 1667, 1578, 1369, 1305, $1153 \mathrm{~cm}^{-1}$. ${ }^{1} \mathrm{H}$ NMR (DMSO- $\left.d_{6}\right): \delta=10.28($ br s, $1 \mathrm{H}), 8.51$ (br s, $\left.2 \mathrm{H}\right), 1.41$ (s, $18 \mathrm{H})$.

${ }^{13} \mathrm{C}$ NMR (DMSO- $\left.d_{6}\right): \delta=158.5(2 \mathrm{C}), 158.2(\mathrm{br} \mathrm{s}), 79.5(2 \mathrm{C}), 27.8$ (6 C).

The ${ }^{1} \mathrm{H}$ NMR spectrum is identical with that of literature, ${ }^{21}$ no ${ }^{13} \mathrm{C}$ NMR and IR spectra were given.

\section{Crystal Structure ${ }^{30}$}

Crystal data: $\mathrm{C}_{11} \mathrm{H}_{21} \mathrm{~N}_{3} \mathrm{O}_{4}, \quad \mathrm{FW}=259.31$, colorless prism of $0.57 \times 0.28 \times 0.26 \mathrm{~mm}$ from hexanes, $T=100(2) \mathrm{K}$, triclinic, space group $P-1, a=11.6836(5) \AA, b=16.1253(6) \AA, c=16.3857(6) \AA$, $\alpha=88.442(2)^{\circ}, \beta=84.200(2)^{\circ}, \gamma=70.064(2)^{\circ}, \quad V=2887.15(19)$ $\AA^{3}, \quad Z=8 \quad\left(Z^{\prime}=4\right), \quad D_{\mathrm{c}}=1.193 \quad \mathrm{~g} \cdot \mathrm{cm}^{-3}, \quad \mu=0.091 \quad \mathrm{~mm}^{-1}$, $\lambda(\mathrm{MoK} \alpha)=0.71073 \AA$. Of 68471 reflections measured, 16711 were unique. Refinement of $F^{2}$ using the program SHELXTL ${ }^{31}$ concluded with $R 1=0.0664$ and $w R 2=0.1229$ for 689 parameters and all data. The structure contains four chemically identical but crystallographically different molecules assembled in bis-NH $\cdots \mathrm{N}$ hydrogen bonded pairs.

\section{$N, N^{\prime}$-Bis(tert-butoxycarbonyl)- $N$-(3-trimethylstannylben- \\ zyl)guanidine (10)}

A solution of $N, N^{\prime}$-bis (tert-butoxycarbonyl)guanidine $(\mathbf{9 a} ; 0.583 \mathrm{~g}$, $2.252 \mathrm{mmol}, 2$ equiv) and $\mathrm{Ph}_{3} \mathrm{P}(0.443 \mathrm{~g}, 1.689 \mathrm{mmol}, 1.5$ equiv $)$ in anhyd toluene $(10 \mathrm{~mL})$ was cooled in an ice bath under argon. 3(Trimethylstannyl)benzyl alcohol (2; $0.305 \mathrm{~g}, 1.126 \mathrm{mmol})$ dissolved in anhyd toluene $(2 \mathrm{~mL})$ and DIAD $(0.321 \mathrm{~g}, 0.31 \mathrm{~mL}, 1.689$ mmol, 1.5 equiv) were added and the stirring was continued for $5 \mathrm{~h}$ at r.t. (TLC: hexanes-EtOAc, 5:1, $R_{f}=0.85$ ). The solvent was evaporated under reduced pressure and the residue was purified by flash chromatography $\left(\mathrm{CH}_{2} \mathrm{Cl}_{2}\right.$-hexanes, $\left.3: 1\right)$ to give precursor $10(0.503$ $\mathrm{g}, 87 \%$ ) as colorless crystals; $\mathrm{mp} 89-90^{\circ} \mathrm{C}$ (hexanes, r.t. to $-18{ }^{\circ} \mathrm{C}$ ). IR (Si, film): 3383, 2979, 2930, 1716, 1612, 1296, 1240, $1149 \mathrm{~cm}^{-1}$. ${ }^{1} \mathrm{H} \mathrm{NMR}\left(\mathrm{CDCl}_{3}\right): \delta=9.43$ and $9.30(2 \mathrm{br} \mathrm{s}, 2 \mathrm{H}, 2 \times \mathrm{NH}), 7.45-$ $7.18(\mathrm{~m}, 4 \mathrm{H}), 5.15(\mathrm{~s}, 2 \mathrm{H}), 1.47$ and $1.33(2 \mathrm{~s}$, each $9 \mathrm{H}), 0.25$ [s, $\left.J\left({ }^{117 / 119} \mathrm{Sn}, \mathrm{H}\right)=55.1,52.8 \mathrm{~Hz}, 9 \mathrm{H}\right]$.

${ }^{13} \mathrm{C} \mathrm{NMR}\left(\mathrm{CDCl}_{3}\right): \delta=163.8,160.9,155.1,141.9,138.3,135.0$ $\left[J\left({ }^{117 / 119} \mathrm{Sn}, \mathrm{C}\right)=37.5 \mathrm{~Hz}\right], 134.3\left[J\left({ }^{117 / 1119} \mathrm{Sn}, \mathrm{C}\right)=36.0 \mathrm{~Hz}\right], 127.8$ $\left[J\left({ }^{117 / 119} \mathrm{Sn}, \mathrm{C}\right)=47.4 \mathrm{~Hz}\right], 127.1\left[J\left({ }^{117 / 119} \mathrm{Sn}, \mathrm{C}\right)=10.0 \mathrm{~Hz}\right], 84.0$, 78.8, 47.6, 28.3 (3 C), 27.8 (3 C), -9.4 (3 C). 
Anal. Calcd for $\mathrm{C}_{21} \mathrm{H}_{35} \mathrm{~N}_{3} \mathrm{O}_{4} \mathrm{Sn}$ : C, 49.24; H, 6.89; N, 8.20. Found: C, 49.57; H, 6.99; N, 8.27.

\section{Crystal Structure ${ }^{30}$}

Crystal data: $\mathrm{C}_{21} \mathrm{H}_{35} \mathrm{~N}_{3} \mathrm{O}_{4} \mathrm{Sn}, \quad \mathrm{FW}=512.21$, colorless oval of $0.45 \times 0.34 \times 0.28 \mathrm{~mm}$ from DMF, $T=100(2) \mathrm{K}$, monoclinic, space group $P 2{ }_{1} / c, \quad a=11.8026(7) \quad \AA, \quad b=12.7556(8) \quad \AA$, $c=16.6750(10) \AA, \beta=102.388(1)^{\circ}, V=2452.0(3) \AA^{3}, Z=4$, $D_{\mathrm{c}}=1.388 \mathrm{~g} \cdot \mathrm{cm}^{-3}, \mu=1.071 \mathrm{~mm}^{-1}, \lambda(\mathrm{MoK} \alpha)=0.71073 \AA$. Of 44175 reflections measured, 7150 were unique. Refinement of $F^{2}$ using the program SHELXTL ${ }^{31}$ concluded with $R 1=0.0252$ and $w R 2=0.0626$ for 271 parameters and all data.

\section{3- $\left[{ }^{131}\right.$ I] Iodobenzylguanidine $\left(\left[{ }^{131}\right.\right.$ I]MIBG, $\left.\left[{ }^{131} I\right] 12\right)$}

The labeling was performed in a sealed conical vial. To a solution of $\quad N, N^{\prime}$-bis(tert-butoxycarbonyl)- $N$-(3-trimethylstannyl)benzylguanidine $(10 ; 0.2 \mathrm{mg}, 0.39 \mu \mathrm{mol})$ in $\mathrm{MeOH}(50 \mu \mathrm{L})$ were added $\mathrm{AcOH}\left(100 \mu \mathrm{L}\right.$ ), and $\left.{ }^{131} \mathrm{I}\right] \mathrm{NaI}$ (in $0.1 \mathrm{M} \mathrm{NaOH}, 6 \mu \mathrm{L}, 45.9 \mathrm{MBq}$ ). The labeling was initiated by the addition of an aq solution of chloramine- $\mathrm{T}(20 \mu \mathrm{L}, 2.8 \mathrm{mg} / \mathrm{mL})$. The reaction mixture was stirred at r.t. for $10 \mathrm{~min}$ to form the intermediate $\left[{ }^{131} \mathrm{I}\right] 11$ (TLC: $\mathrm{MeOH}-2 \mathrm{M}$ ammonia-1 $\left.\mathrm{M} \mathrm{NH} \mathrm{NO}_{3}, 27: 2: 1 ; R_{f}=0.77\right)$. The reaction was quenched with aq $\mathrm{Na}_{2} \mathrm{~S}_{2} \mathrm{O}_{5}(50 \mu \mathrm{L}, 4 \mathrm{mg} / \mathrm{mL})$. Afterwards, $\mathrm{CF}_{3} \mathrm{CO}_{2} \mathrm{H}(100 \mu \mathrm{L})$ was added and the sealed vial was heated for 15 min at $110^{\circ} \mathrm{C}$ to give $\left[{ }^{131} \mathrm{I}\right] \mathbf{1 2}$. The reaction mixture was adjusted to $\mathrm{pH} 4$ with aq $2 \mathrm{M} \mathrm{NaOH}(600 \mu \mathrm{L})$ and the crude product was purified via HPLC [Prontosil C18-asc-EPS column, $5 \mu \mathrm{m}, 10 \times 250$ $\mathrm{mm}$, Bischoff; liquid phase: $\mathrm{MeOH}-0.05 \mathrm{M}$ phosphate buffer ( $\mathrm{pH}$ 4.5) $(1: 1), 3 \mathrm{~mL} / \mathrm{min} ; t_{\mathrm{R}}=11 \mathrm{~min}$. To the isolated fraction (44.6 MBq, 97\% radiochemical yield) was added 2,5-dihydroxybenzoic acid $(0.3 \mathrm{mg})$ and the solvent was removed gently at $35^{\circ} \mathrm{C}$ under reduced pressure. The residue was redissolved in a solution $(1.2 \mathrm{~mL})$ of $0.05 \mathrm{M}$ phosphate-buffered saline ( $\mathrm{pH} 4.5)-\mathrm{EtOH}-$ benzyl alcohol (94:5:1); $37.3 \mathrm{MBq}$ (81\% radiochemical yield); purity $>99 \%$.

TLC: $\mathrm{MeOH}-2 \mathrm{M}$ ammonia-1 $\mathrm{M} \mathrm{NH}_{4} \mathrm{NO}_{3}(27: 2: 1) ; R_{f}=0.54$.

HPLC: Zorbax SB aq C18; $5 \mu \mathrm{m}, 4.6 \times 250 \mathrm{~mm}$, Agilent; liquid phase: $\mathrm{MeOH}-0.05 \mathrm{M}$ phosphate buffer $\mathrm{pH} 4.5$ (4:6); flow rate: 1 $\mathrm{mL} / \mathrm{min}$; detection: $\lambda=254 \mathrm{~nm} ; t_{\mathrm{R}}=8.2 \mathrm{~min}$.

\section{Acknowledgment}

This work was supported by Grant No. L420-N19 from the Austrian Science Fund (FWF). We thank S. Felsinger for recording the NMR spectra.

\section{References}

(1) Nakajo, M.; Shapiro, B.; Copp, J.; Kalff, V.; Gross, M. D.; Sisson, J. C.; Beierwaltes, W. H. J. Nucl. Med. 1983, 24, 672.

(2) Wafelman, A. R.; Hoefnagel, C. A.; Maes, R. A. A.; Beijnen, J. H. Eur. J. Nucl. Med. 1994, 21, 545.

(3) Shapiro, B.; Gross, M. D. Med. Pediatr. Oncol. 1987, 15, 170.

(4) Rubello, D.; Bui, C.; Casara, D.; Gross, M. D.; Fig, L. M.; Shapiro, B. Eur. J. Endocrinol. 2002, 147, 13.

(5) Valdes Olmos, R. A.; Hoefnagel, C. A.; van der Schoot, J. B. Eur. J. Nucl. Med. Mol. Imaging 1993, 20, 515.
(6) Howard, J. P.; Maris, J. M.; Kersun, L. S.; Huberty, J. P.; Cheng, S. C.; Hawkins, R. A.; Matthay, K. K. Pediatr. Blood Cancer 2005, 44, 232.

(7) Hunter, H. D.; Zhu, X. J. Labelled Compd. Radiopharm. 1999, 42, 653.

(8) Mangner, T. J.; Wu, J.-L.; Wieland, D. M.; Beierwaltes, W. H. J. Nucl. Med. 1981, 22, P12.

(9) Mertens, J.; Vanryckeghem, W.; Gysemans, M.; Eersels, J.; Finda-Panek, E.; Carlsen, L. Eur. J. Nucl. Med. Mol. Imaging 1987, 13, 380.

(10) Verbruggen, R. F. Appl. Radiat. Isot. 1987, 38, 303.

(11) Amartey, J. K.; Al-Jammaz, I.; Lambrecht, R. M. Appl. Radiat. Isot. 2001, 54, 711.

(12) Neves, M.; Paulo, A.; Patricio, L. Appl. Radiat. Isot. 1992, 43, 337.

(13) Vaidyanathan, G.; Zalutsky, M. R. Appl. Radiat. Isot. 1992, 44, 621.

(14) Rossouw, D. D.; Macheki, L. J. Labelled Compd. Radiopharm. 2009, 52, 499.

(15) Vaidyanathan, G.; Affleck, D. J.; Alston, K. L.; Zalutsky, M. R. J. Labelled Compd. Radiopharm. 2007, 50, 177.

(16) Hunter, D. H.; Goel, A.; Flanagan, R. J. US Patent 5565185, 1996; Chem. Abstr. 1996, 124, 260616.

(17) Koldobsky, A. B.; Vakhmistrov, V. E.; Shilova, O. S.; Kalinin, V. N.; Tehrani, K. A.; De Kimpe, N. Org. Prep. Proced. Int. 1998, 30, 447.

(18) Efange, S. M. N.; Michelson, R. H.; Khane, A. B.; Thomas, J. R. J. Med. Chem. 1993, 36, 1754.

(19) Kumara Swamy, K. C.; Bhuvan Kumar, N. N.; Balaraman, E.; Pavan Kumar, K. V. P. Chem. Rev. 2009, 109, 2551.

(20) Yong, Y. F.; Kowalski, J. A.; Lipton, M. A. J. Org. Chem. 1997, 62, 1540.

(21) Feichtinger, K.; Sings, H. L.; Baker, T. J.; Matthews, K.; Goodman, M. J. Org. Chem. 1998, 63, 8432.

(22) Dodd, D. S.; Kozikowski, A. P. Tetrahedron Lett. 1994, 35 , 977.

(23) Vaidyanathan, G.; Zalutsky, M. R. J. Org. Chem. 1997, 62, 4867.

(24) Bergeron, R. J.; McManis, J. S. J. Org. Chem. 1987, 52, 1700 .

(25) Kessler, R. M.; Ansari, M. S.; de Paulis, T.; Schmidt, D. E.; Clanton, J. A.; Smith, H. E.; Manning, R. G.; Gillespie, D.; Ebert, M. H. J. Nucl. Med. 1991, 32, 1593.

(26) Schirbel, A.; Zolle, I.; Hammerschmidt, F.; Berger, M. L.; Schiller, D.; Kvaternik, H.; Reiners, C. Radiochim. Acta 2004, 92, 297.

(27) Wafelman, A. R.; Suchi, R.; Hoefnagel, C. A.; Beijnen, J. H. Eur. J. Nucl. Med. Mol. Imaging 1993, 20, 614.

(28) Chattopadhyay, S.; Das, M. K.; Sarkar, B. R.; Prabhakar, G.; Mehra, K. S.; Ramamoorthy, N. Appl. Radiat. Isot. 2000, 54, 241.

(29) Mikenda, W. Vib. Spectrosc. 1992, 3, 327.

(30) CCDC 873052 (9a) and 859313 (10) contain the supplementary crystallographic data for this paper. These data can be obtained free of charge from the Cambridge Crystallographic Data Centre via www.ccdc.ac.uk/data_request/cif.

(31) SHELXTL Version 2008; Bruker AXS Inc: Madison WI, 2008. 